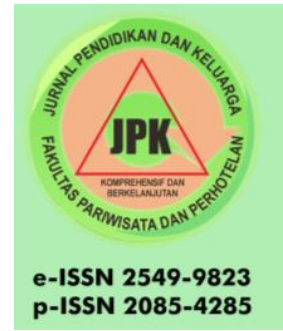

JURNAL PENDIDIKAN DAN KELUARGA

Vol. 11 No. 2, 2019 Page 27-37

DOI: https://doi.org/10.24036/jpk/vol11-iss02

available at http://jpk.ppj.unp.ac.id/index.php/jpk/index

\title{
PENGARUH KETERLIBATAN KERJA TERHADAP PRODUKTIVITAS KARYAWAN DI FAVEHOTEL OLO PADANG
}

\author{
Amanda Ratna Dilla ${ }^{1}$, Yuliana ${ }^{2}$ \\ ${ }^{1,2}$ Program Studi D4 ManajemenPerhotelan \\ FPP Universitas Negeri Padang \\ Email: yuliana@fpp.unp.ac.id \\ Published: 2019-12-31 \\ DOI: https://doi.org/10.24036/jpk/vol11-iss02/616 \\ URL:http://jpk.ppi.unp.ac.id/index.php/jpk/article/view/616
}

\begin{abstract}
This reseach aims to determine the effect of work involvement on employee productivity at Favehotel Olo Padang. This type of research is classified as associative quantitative research. The puopulationin this the reseach were all employees at Favehotel Olo Padang. The reseach sample ammounted to 38 employees with the sampling technique is saturated sampling. Data collection techniques were carried out using a questionnaire with a Likert scale that had been tested for validity ang reliability. Data were analyzed by sample linear regression testing through the help of the SPSS computer Program version 16.00. the results of the study show: 1) The involvement of employees at Favehotel Olo Padang is in poor category (39,48\% ). 2) Employees productivity in the good category $(42,10 \%) .3) \quad \mathrm{R}$ square 0.115 and a significance value of 0.037 which means that there is a significant influence between work involment on productivity is $11,5 \%$ while $88.5 \%$ is influenced by other factors
\end{abstract}

Keywords: culinary, tourism, hospitality.

\begin{abstract}
Abstrak
Penelitian ini bertujuan untuk mengetahui pengaruh keterlibatan kerja terhadap produktivitas karyawan di Favehotel Olo Padang. Jenis penelitian ini diklasifikasikan sebagai penelitian kuantitatif asosiatif. Populasi dalam penelitian ini adalah semua karyawan di Favehotel Olo Padang. Sampel penelitian berjumlah 38 karyawan dengan teknik pengambilan sampel adalah sampling jenuh. Teknik pengumpulan data dilakukan menggunakan kuesioner (angket) dengan skala likert yang telah diuji validitas dan reliabilitasnya. Data dianalisis dengan pengujian regresi linier sederhana melalui bantuan Program Komputer SPSS versi 16.00. Hasil penelitian menunjukkan: 1) Keterlibatan kerja karyawan di Favehotel Olo Padang berada pada kategori kurang baik $(39,48 \%)$. 2) produktivitas karyawan berada pada kategori baik (42,10\%) .3) R Square 0,115 dan nilai signifikansi 0,037 yang artinya terdapat pengaruh yang signifikan antara keterlibatan kerja terhadap produktivitas adalah $11,5 \%$ sedangkan $88,5 \%$ di pengaruhi oleh faktor lain.
\end{abstract}

Kata Kunci: Keterlibatan Kerja, Produktivitas Karyawan.

This is an open access article distributed under the Creative Commons 4.0 Attribution License, which permits unrestricted use, distribution, and reproduction in any medium, provided the original work is properly cited. (C2017 by author and Universitas Negeri Padang. 


\section{Pendahuluan}

Saat ini industri perhotelan di Indonesia terus berkembang seiring dengan perkembangan dunia usaha yang ditandai dengan terus bertambahnya jumlah hotel yang ada. Dengan perkembangan tersebut persaingan antar hotel akan semakin meningkat. Oleh sebab itu hotel harus didukung oleh berbagai aspek agar dapat bersaing dengan hotel lain, bukan hanya pelayanan yang baik tetapi perlu adanya desain hotel yang tanggap terhadap kebutuhan dan kenyamanan yang erat hubungannya dengan perilaku penghuni hotel.

Hotel merupakan salah satu jenis akomodasi yang sangat dikenal oleh masyarakat sebagai akomodasi penginapan, makanan serta minuman dan hal-hal yang berkaitan dengan kebutuhan tamu untuk menginap. Menurut Sulastiyono (2011: 5) "Hotel adalah suatu perusahaan yang dikelola oleh pemiliknya dengan menyediakan pelayanan makanan, minuman dan fasilitas kamar untuk tidur kepada orang-orang yang melakukan perjalanan dan mampu membayar dengan jumlah yang wajar sesuai dengan pelayanan yang diterima tanpa adanya perjanjian khusus". Satu hal yang penting yaitu bahwa keberhasilan berbagai aktivitas didalam perusahaan dalam mencapai tujuan bukan hanya tergantung pada keunggulan teknologi, dana operasi yang tersedia, sarana ataupun prasana yang dimiliki melainkan juga tergantung pada aspek sumber daya manusia. Berkembang atau tidaknya suatu perusahaan atau indutri perhotelan tergantung pada sumber daya manusia.

Sumber Daya Manusia (SDM) adalah daya yang bersumber dari manusia dapat juga disebut tenaga atau kekuatan (energi atau power). Tenaga, daya, kemampuan atau kekuuatan terdapat pula pada unsur alam yang lain (Sedarmayanti 2009: 1). Faktor sumber daya manusia ini merupakan elemen yang harus diperhatikan oleh perusahaan dimana iklim kompetisi yang dihadapi akan sangat berbeda. Hal ini memaksa setiap perusahaan harus dapat bekerja dengan lebih efisien, efektif dan produktif. Tingkat kompetisi yang tinggi akan memacu tiap perusahaan untuk dapat mempertahankan kelangsungan hidupnya dengan memberikan perhatian pada aspek sumber daya manusia. Jadi manusia dapat dipandang sebagai faktor penentu karena ditangan manusialah segala inovasi akan direalisir dalam upaya mewujudkan tujuan perusahaan. setiap perusahaan pada umumnya selalu berusaha meningkatkan produktivitas kerja karyawan.

Menurut Rivanto dalam Via Gusti. Yuliana, Hijriyantomi Suyuthie (2015) Produktifitas kerja adalag sebagai suatu konsep yang mewujudkan adanya kaitan antara output (hasil kerja) dengan waktu yang dibuthkan untuk menghasilkan produk dari seorang tenaga kerja, maksudnya bahwa produktivitas seorang tenaga kerja sangat berkaitan dengan hasil kerja yang di peroleh terhadap waktu yang di perlukan untuk menghasilkannya.

Produktivitas kerja adalah ukuran yang menunjukkan pertimbangan antara input dan output yang dikeluarkan perusahaan serta peran tenaga kerja yang dimiliki persatuan waktu (Sunyoto 2015: 203). Keinginan setiap perusahaan atau organisasi untuk mendapatkan produktivitas kerja karyawan yang efektif dan efisien membuat para karyawannya dapat melakukan keterlibatan kerja. Dengan adanya keinginan membuat karyawan harus mempunyai keterlibatan kerja yang matang serta memiliki keinginan untuk melibatkan diri dalam pekerjaan mereka. Indikator yang ditempuh untuk memenangkan persaiangan tersebut karyawan dituntut untuk mempunyai kemampuan, meningkatkan hasil yang dicapai, semangat kerja, pengembangan diri, mutu dan efiseiensi yang tinggi agar dapat mampu bersaing mampu memenuhi kebutuhan organisasi dan bersaing diluar organisasi tempat bekerja secara nasional maupun internasioanal.

Faktor-faktor yang mempengaruhi produktivitas kerja menurut Anoraga (2009: 56-57) pekerjaan yang menarik, upah yang baik, keamanan dan perlindungan dalam bekerja, Penghayatan atas maksud dan makna pekerjaan, lingkungan atau sarana kerja yang baik, promosi dan perkembangan diri sejalan dengan perusahaan, merasa terlibat dalan kegiatan

This is an open access article distributed under the Creative Commons 4.0 Attribution License, which permits unrestricted use, distribution, and reproduction in any medium, provided the original work is properly cited. (C2017 by author and Universitas Negeri Padang. 
organisasi, pengertian dan simpati atas persoalan-persoalan pribadi, kesetiaan pimpinan pada pekerjaan, disiplin kerja yang keras.

Menurut Rivai dan Mulyadi (2012: 246) menjelaskan, "keterlibatan kerja adalah derajat sejauh mana seseorang memihak secara psikologis terhadap pekerjaanya dan menganggap tingkat kinerjanya penting untuk harga diri. Semua karyawan yang ada dalam suatu perusahaan harus terlihat dalam pekerjaanya masing-masing dan mrmiliki rasa kepedulian terhadap pekerjaanya demi mencapai tujuan perusahaan. Keterlibatan dalam aktifitas kerja penting untuk diperhatikan karena dengan adanya keterlibatan kerja karyawan akan menyebabkan mereka akan mau dan senang bekerja sama baik dengan pimpinan atau dengan sesama teman kerja. Salah satu cara yang dapat dipakai untuk memancing keterlibatan karyawan adalah dengan partisipasi atau keterlibatan mereka dalam berbagai kesempatan pembuatan keputusan. Indikator keterlibatan kerja meliputi partisipasi kerja, keikutsertaan dan kerja sama.

Berdasarkan pra penelitian yang penulis lakukan di Favehotel Olo Padang pada tanggal 20 Februari 2019, peneliti mendapatkan informasi keluhan mengenai produktivitas kerja tentang sistem kekeluargaan dalam penerimaan karyawan hotel sehingga karyawan yang bekerja diposisikan tidak sesuai dengan latar belakang pendidikan terakhir seperti pendidikan terakhir S1 Hukum diposisikan pada bagian front office. Masalah selanjutnya banyaknya karyawan yang tidak hadir dalam pelatihan umum standar hotel yang dilakukan oleh human resources department seperti pelatihan standar hotel dalam greeting yang telah ditetapkan oleh perusahaan tetapi tidak diterapkan oleh karyawan. Menurunnya semangat kerja dikarenakan tidak adanya pemberian sertifikat penghargaan dari pihak manajemen untuk karyawan berprestasi seperti best employee of the month yang berguna bagi karyawan sebagai nilai tambah untuk bekerja diperusahaan lain dan meningkatkan jenjang karir. Peneliti melihat adanya masalah yang terkait keterlibatan kerja karyawan seperti adanya karyawan back office yang bermain game online pada saat jam operasional sehingga kurangnya partisipasi karyawan dalam menyelesaikan pekerjaan tepat waktu. Selanjutnya adanya karyawan yang makan di ruangan kerja dimana Favehotel Olo Padang menyediakan kantin khusus karyawan yang ingin makan dan minum sehingga memperlambat aktivitas pekerjaan. Masalah selanjutnya kurangnya pengawasan dari atasan terhadap karyawan housekeeping yang merokok di kamar tamu yang telah selesai mereka bersihkan sehingga menyebabkan tamu Complaint dikarenakan bau asap rokok dan melanggar peraturan dari peusahaan. Masalah lainnya tidak adanya partisipasi karyawan security dalam mengatur posisi parkir kendaraan tamu sehingga tamu lain kesulitan dalam mengeluarkan kendaraan.

Pentingnya penelitian ini penulis angkat adalah untuk mengetahui tentang pengaruh keterlibatan kerja terhadap produktivitas karyawan di Favehotel Olo Padang, sedangkan berdasarkan pengamatan penulis di Favehotel Olo Padang menemukan masalah pada keterlibatan kerja karyawan. Jika masalah ini tetap dibiarkan maka terjadinya penurunan produktivitas karyawan yang tidak hanya merugikan karyawan itu sendiri tetapi juga menimbulkan kerugian bagi hotel. Dampak lainnya akan terjadinya komplain tamu yang berkelanjutan yang membuat citra hotel menjadi rusak dan menurunnya pengunjung dalam jangka waktu yang panjang. Tujuan dari penelitian ini adalah untuk mengetahui pengaruh keterlibatan kerja terhadap produktivitas karyawan di Favehotel Olo Padang ditinjau dari indikator partisipasi kerja, keikutsertaan, kerja sama, kemampuan, meningkatkan hasil yang dicapai, semangat kerja, pengembangan diri, mutu dan efisiensi.

\section{Metode}

Jenis penelitian ini adalah penelitian kuantitatif dengan metode asosiatif kausal. Populasi dari penelitian ini adalah seluruh karyawan di Favehotel Olo Padang kecuali Head Of Department dengan jumlah 38 orang. Teknik pengambilan sampel yang digunakan adalah sampel jenuh. Data dalam penelitian Pengaruh Keterlibatan Kerja Terhadap Produktivitas 
Karyawan di Favehotel Olo Padang menggunakan data primer untuk variabel X dan Y dengan cara menyebar angket kepada 38 orang karyawan dan peneliti melakukan uji coba instrumen di Hotel Amaris Padang.

Instrumen penelitian yang digunakan adalah kuesioner (angket) yang disusun menurut skala likert. Penelitian ini menggunakan rumus penelitian rata-rata ideal (Mi) dan standardeviasi (Sdi). Klarifikasi menurut Arikunto (2017) dapat dibagi menjadi 5 kategori yaitu:

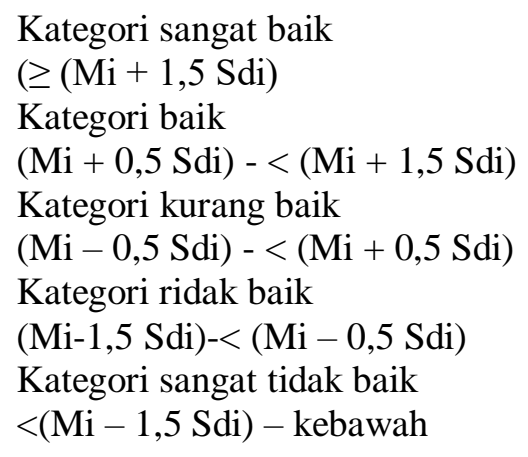

\section{Uji Reliabilitas}

Setelah dilakukan uji validitas, maka selanjutnya instrumen tersebut diuji realibilitas (kehandalan) nya. Analisis reliabilitas pada penelitian ini dilkaukan dengan menggunakan program SPSS versi 16. Tujuan dari pengujian reliabilitas ini adalah untuk menetahui kehandalan dari suatu instrumen. Uji reliabilitas instrumen dengan menggunakan rumus Alpha Cronbach yang dikemukakan Arikunto (2010: 22) bahwa "Reliabilitas adalah suatu pengertian bahwa suatu instrumen cukup untuk dapat dipercaya dan digunakan sebagai alat pengumpul data karena data tersebut sudah baik". Pengambilan keputusan untuk uji reliabilitas adalah sebagai berikut:

Jika suatu variabel nilai reliabilitasnya (Alpha Cronbach) $\geq 0,06$ maka variabel tersebut dikatakan reliabel.

Jika suatu variabel nilai reliabilitasnya (Alpha Cronbach) $<0,06$ maka variabel tersebut dikatakan tidak reliabel.

Table 1 Tabel 1 Interprestasi Nilai r (Alpa Cronbach)

\begin{tabular}{ll}
\hline Alpha Coronbach & Interprestasi \\
\hline $0,90-1,00$ & Sangat tinngi \\
\hline $0,70-0,90$ & Tinggi \\
\hline $0,40-0,70$ & Sedang \\
\hline $0,20-0,40$ & Rendah \\
\hline $0,00-0,20$ & Sangat Rendah \\
\hline
\end{tabular}

Table 2 Reliability Statistics

\begin{tabular}{ll}
\hline Reliability Statistics & \\
\hline Cronbach's Alpha & N of Items \\
\hline .852 & 15 \\
\hline Sumber: Hasil Olah Data (2019) &
\end{tabular}

Sumber: Hasil Olah Data (2019) 
Terdapat nilai reliabilitas variabel $\mathrm{X}$ keterlibatan kerja sebesar 0,852 . Nilai reliabilitas keterlibatan kerja $\mathrm{X}$ tergolong tinggi. Jika nilai reliabilitas > 0,6 maka dikatakan reliabel.

Table 3 Reliability Statistics

\begin{tabular}{ll}
\hline Reliability Statistics & \\
\hline Cronbach's Alpha & N of Items \\
\hline .918 & 30 \\
\hline
\end{tabular}

Sumber: Hasil Olah Data (2019)

Terdapat nilai reliabilitas variabel Y Produktivitas sebesar 0,918. Nilai reliabilitas Produktivitas karyawan $\mathrm{Y}$ tergolong tinggi. Jika nilai reliabilitas $>0,6$ maka dikatakan reliabel.

\section{Uji Persyaratan Analisis} Uji Normalitas

Uji normalitas digunakan untuk mengetahui apakah data berdistibusi secara normal atau tidak. Pengujian noarmalitas dianalisa dengan menggunakan uji one sample kolmogrov smirnov dengan alat bantu SPSS versi 16 diantaranya (1) Nilai Sig./signifikan atau probabilitas $\leq 0,05$, distibusi adalah tidak normal (asimetris). (2) Nilai Sig./signifikan atau probabilitas $>0,05$, distribusi adalah normal (simetris).

\section{Uji Homogenitas}

Uji homogenitas dilakukan untuk melihat apakah sampel yang berasal dari populasi memiliki karateristik yang sama atau tidak. Untuk pengujian ini digunakan uji Test of Homogenity of Variances. Kriteria pengujiannya adalah:

Jika nilaisignifikan (Sig) atau nilai probabilitas $(\mathrm{p}) \geq 0,05$ maka dapat dikatakan data tersebut berasal dari populasi yang mempunyai varian yang sama atau data bersifat homogen. Jika nilai signifikan (Sig) atau nilai probabilitas $(\mathrm{p})<0,05$ maka dapat dikatakan data tersebut berasal dari populasi yang mempunyai varian yang tidak sama atau data bersifat tidak homogen.

\section{Uji Linearitas}

Uji linearitas bertujuan untuk mengetahui apakah hubungan variabel $\mathrm{X}$ dan variabel $\mathrm{Y}$ bersifat linaer atau tidak. Pengujian linearitas dilakukan dengan menggunakan program SPSS Versi 16. Dua variabel dikatakan mempunyai hubungan linear bila nilai Deviation from Linearity $>0,05$.

\section{Pengujian Hipotesis}

\section{Analisis Regresi Linier Sederhana}

Pengujian ini berfungsi untuk mengetahui seberapa jauh pengaruh satu variabel ke variabel yang lain dilakukan dengan menggunakan Program SPSS dengan rumus sebagai berikut:

$Y=a+b X$

Dimana:

$\mathrm{Y}=$ Subjek dalam variabel yang diprediksikan

$\mathrm{a}=$ Harga $\mathrm{Y}$ bila $\mathrm{X}=0$ (Harga Konstan)

$\mathrm{b}=$ Koefesien yang menunjukkan arah peningkatan atau penurunan variable

dependen pada variabel independen.

\section{Koefesiensi Determinasi}


Pengujian ini berfungsi untuk mengetahui seberapa jauh pengaruh satu variabel ke variabel yang lain dilakukan dengan menggunakan dengan rumus sebagai berikut: Nilai a dapat dihitung dengan menggunakan rumus dibawah ini:

$$
\mathrm{a}=\frac{\sum \mathbf{y}\left(\sum \mathbf{x}^{2}\right)-\sum \mathbf{x}\left(\sum \mathbf{x y}\right)}{\mathbf{n} \sum \mathbf{x}^{2}-\left(\sum \mathbf{x}\right) 2}
$$

sedangkan untuk harga $\mathrm{b}$ dapat dihitung dengan menggunakan rumus:

$$
\mathrm{b}=\frac{n \sum \mathrm{xy}-\left(\sum \mathrm{x}\right)\left(\sum y\right)}{n \sum x^{2}-\sum(x)^{2}}
$$

sedangkan untuk menyatakan besar atau kecilnya pengaruh $\mathrm{X}$ terhadap $\mathrm{Y}$ dapat ditentukan dengan rumus koefisien sebagai berikut:

$$
\begin{aligned}
& K p=r^{2} \times 100 \% \\
& \text { Keterangan: } \\
& \mathrm{Kp}=\text { Besaran koefisien penentu } \\
& \mathrm{R} \quad=\text { Koefisien Korelasi }
\end{aligned}
$$

Kriteria pengambilan keputusan adalah:

Besarnya pengaruh Keterlibatan Kerja terhadap Produktivitas karyawan di tentukan oleh nilai $\mathrm{R}$.

Jika nilai signifikan $\mathrm{R}^{2} \leq 0,05$, maka pengaruh keterlibatan kerja terhadap produktivitas karyawan signifikan.

Jika nilai $\mathrm{R}^{2}>0,05$, maka pengaruh keterlibatan kerja terhadap produktivitas karyawan tidak signifikan.

\section{Hasil Dan Pembahasan}

\section{Variabel Keterlibatan Kerja $(X)$}

Berdasarkan hasil penelitian, dapat dijekaslan bahwa dari 38 responden maka variabel keterlibatan kerja dapat dikategorikan kurang baik 39,48\%. Partisipasi kerja adalah dengan kategori baik serta memiliki persentase sebesar $34,21 \%$, keikutsertaan dengan kategori kurang baik serta memiliki persentase $42,12 \%$ dan kerja sama dengan kategori kurang baik dan memiliki persentase 44,73\%. Sehingga dapat disimpulkan bahwa Keterlibatan Kerja di Favehotel Olo Padang adalah dengan kategori Kurang Baik.

Data variabel keterlibatan kerja (X) dikumpulkan melalui pernyataan yang terdiri dari 15 butir pernyataan yang telah diuji validitas dan reliabilitasnya. Selanjutnya kuesioner disebarkan kepada 38 responden untuk di jawab. Bersumber dari pengisian kuesioner maka dapat diperoleh deskripsi data sebgai berikut:

Table 4 Distribusi Frekuensi Variabel Keterlibatan Kerja

\begin{tabular}{llll}
\hline Kategori & Skor & f & Persentase(\%) \\
\hline Sangat Baik & $\geq 60$ & 8 & 21,05 \\
\hline Baik & $\geq 50-<60$ & 12 & 31,57 \\
\hline Kurang Baik & $\geq 40-<50$ & 15 & 39,48 \\
\hline Tidak Baik & $\geq 30-<40$ & 3 & 7,90 \\
\hline Sangat Tidak Baik & $<30$ & 0 & 0 \\
\hline Total & & 38 & 100 \\
\hline
\end{tabular}

Sumber: Hasil Olahan Data Primer (2019)

This is an open access article distributed under the Creative Commons 4.0 Attribution License, which permits unrestricted use, distribution, and reproduction in any medium, provided the original work is properly cited. (C2017 by author and Universitas Negeri Padang. 
Berdasarkan pengkategorian skor dan nilai rata-rata pada statistik hasil penelitian, terlihat bahwa penilaian karywan tentang keterlibatan kerja sebesar 39,48\% berada pada rentang $\geq 40$ - <50 dengan kategori kurang baik. Sehingga dapat disimpulkan bahwa penilaian tentang keterlibatan kerja di Favehotel Olo Padang adalah kurang baik.

\section{Variabel Produktivitas (Y)}

Berdasarkan hasil penelitian, dapat dijelaskan bahwa dari 38 responden maka variabel produktivitas dikategorikan setuju 42,10\%. Kemudian pada indikator Kemampuan dengan kategori tidak baik dan memiliki persentase sebesar 39,47\%, meningkatkan hasil yang dicapai dengan kategori baik dan memiliki persentase sebesar 39,47\%, semangat kerja dengan kategori kurang baik dan memiliki persentase $47,37 \%$, pengembangan diri dengan kategori kurang baik dan memiliki persentase 47,38\%, mutu dengan kategori kurang baik dan memiliki persentase $39,47 \%$ dan efisiensi dengan kategori kurang baik dan memiliki persentase $36,84 \%$. Sehingga dapat disimpulkan bahwa produktivitas karyawan di Favehotel Olo Padang adalah dengan kategori Kurang baik.

Dalam penelitian ini data tentang produktivitas di peroleh dari menyebar kuesioner yang terdiri dari 30 pernyataan yang di sebar ke 38 karyawan di Favehotel Olo Padang yang telah diuji validitas dan reliabiltasnya. Bersumber dari pengisisan kuesioner maka dapat di peroleh deskripsi data sebgai berikut:

Table 5 Distribusi Frekuensi Produktivitas Karyawan di Favehotel Olo Padang

\begin{tabular}{llll}
\hline Kategori & Skor & F & Persentase $(\%)$ \\
\hline Sangat Baik & $\geq 120$ & 6 & 15,78 \\
\hline Baik & $\geq 100-<120$ & 16 & 42,10 \\
\hline Kurang Baik & $\geq 80-<100$ & 15 & 39,48 \\
\hline Tidak Baik & $\geq 60-<80$ & 1 & 2,64 \\
\hline Sangat Tidak Baik & $<60$ & 0 & 0 \\
\hline Total & & 38 & 100 \\
\hline
\end{tabular}

Sumber: Hasil Olahan Data Primer, 2019

Berdasarkan pengkategorian skor dan nilai rata-rata pada statistik hasil penelitian, terlihat bahwa penilaian karyawan tentang produktivitas karyawan sebesar $39,48 \%$ berada pada rentang $\geq 100-<120$ dengan kategori baik. Sehingga dapat disimpulkan bahwa penilaian karyawan tentang produktivitas di Favehotel Olo Padang.

\section{Uji Persyaratan Analisis}

\section{Uji Normalitas}

Table 6 One-Sample Kolmogorov-Smirnov Test

\begin{tabular}{|c|c|c|c|}
\hline & & Keterlibatan Kerja & Produktivitas \\
\hline $\mathrm{N}$ & & 38 & 38 \\
\hline \multirow[t]{2}{*}{ Normal Parameters } & Mean & 51.76 & 105.29 \\
\hline & Std. Deviation & 8.912 & 13.961 \\
\hline \multirow{3}{*}{$\begin{array}{c}\text { Most } \\
\text { Differences }\end{array}$} & Absolute & .151 & .159 \\
\hline & Positive & .151 & .118 \\
\hline & Negative & -.107 & -.159 \\
\hline \multicolumn{2}{|c|}{ Kolmogorov-Smirnov Z } & .930 & .979 \\
\hline \multicolumn{2}{|c|}{ Asymp. Sig. (2-tailed) } & .353 & .294 \\
\hline
\end{tabular}


Diperoleh nilai Asym, Sig. Untuk variabel Keterlibatan Kerja adalah 0,353 dan untuk produktivitas adalah 0,294 dengan nilai >0,05 maka dapat dikatakan bahwa kedua data terdistribusi normal.

\section{Uji Homogenitas}

Table 7 Test of Homogeneity of Variances

\begin{tabular}{llll}
\hline Produktivitas & & & \\
\hline Levene Statistic & df1 & df2 & Sig. \\
\hline 2.337 & 8 & 15 & .074 \\
\hline
\end{tabular}

Sumber: Hasil Olahan Data Primer, 2019

Dalam penelitian ini di peroleh nilai Sig adalah 0,075 dengan taraf signifikan >0,05. Ini artinya nilai signifikan lebih besar dari taraf signifikan.

\section{Uji Linearitas}

Table 8 ANOVA

\begin{tabular}{|c|c|c|c|c|c|c|c|}
\hline & & & $\begin{array}{l}\text { Sum } \\
\text { quares }\end{array}$ & Df & Mean S & $\mathrm{F}$ & Sig. \\
\hline \multirow{5}{*}{$\begin{array}{lr} & \text { Produkti } \\
* & \text { Keterli } \\
\text { Kerja }\end{array}$} & \multirow{3}{*}{$\begin{array}{l}\text { Between } \\
\text { Groups }\end{array}$} & (Combined) & 4598.811 & 21 & 218.991 & 1.32 & .285 \\
\hline & & Linearity & 833.419 & 1 & $833.41 \mathrm{C}$ & 5.04 & .039 \\
\hline & & $\begin{array}{l}\text { Deviation } \\
\text { Linearity }\end{array}$ & 3765.393 & 20 & $188.27 \mathrm{C}$ & 1.14 & .400 \\
\hline & \multicolumn{2}{|c|}{ Within Groups } & 2642.583 & 16 & 165.161 & & \\
\hline & \multicolumn{2}{|l|}{ Total } & 7241.395 & 37 & & & \\
\hline
\end{tabular}

Sumber: Hasil Olahan Data Primer, 2019

Berdasarkan hasil uji linearitas diatas diperoleh nilai sig 0,400 dengan taraf signifikan > 0,05 . Sehingga dapat disimpulkan bahwa terdapat pengaruh yang linear pada kedua variabel tersebut.

\section{Uji Hipotesis}

Berdasarkan hasil uji regresi linear diperoleh nilai $F$ 4,682 dengan nilai sig. 0,037 <0,05, artinya variabel $\mathrm{X}$ dapat menjelaskan variabel $\mathrm{Y}$ secara signifikan. Jadi variabel keterlibatan kerja mempengaruhi variabel produktivitas karyawan, maka ha diterima ho ditolak.

\section{Koefisien Determinasi}

Table 9 Koefisien Determinasi (R square)

\begin{tabular}{|c|c|c|c|c|}
\hline \multicolumn{5}{|c|}{ Model Summary } \\
\hline Model & $\mathrm{R}$ & R Square & Adjusted R Squal & Std. Error of the Estima \\
\hline 1 & $.339^{\mathrm{a}}$ & .115 & .091 & 13.342 \\
\hline
\end{tabular}

Sumber: Hasil Olahan Data Primer, 2019

$\mathrm{R}$ square $=0,115$ artinya kontribusi atau pengaruh variabel keterlibatan kerja karyawan terhadap produktivitas karyawan adalah $11,5 \%$, sedangkan $88,5 \%$ di pengaruhi oleh faktor lain.

This is an open access article distributed under the Creative Commons 4.0 Attribution License, which permits unrestricted use, distribution, and reproduction in any medium, provided the original work is properly cited. C2017 by author and Universitas Negeri Padang. 


\section{Uji Regresi Linear Sederhana}

Table 10 ANOVA

\begin{tabular}{lllllll}
\hline \multicolumn{2}{l}{ ANOVA $^{\mathrm{b}}$} & \multicolumn{1}{c}{} \\
\hline Model & & Sum of Squa & Df & Mean Sql & F & Sig. \\
\hline \multirow{2}{*}{1} & Regression & 833.419 & 1 & 833.419 & 4.68 & $.037^{\text {a }}$ \\
\cline { 2 - 7 } & Residual & 6407.976 & 36 & 177.999 & & \\
\cline { 2 - 7 } & Total & 7241.395 & 37 & & & \\
\hline
\end{tabular}

a. Predictors: (Constant), keterlibatan kerja

b. Dependent Variable: produktivitas

Nilai $\mathrm{F}$ hit 4,682 dengan sig. $0,037 \leq 0,05$, artinya variabel Keterlibatan Kerja dapat menjelaskan variabel produktivitas secara signifikan.

Table 11 Koefisien Regresi Variabel X terhadap Y

\begin{tabular}{llllll}
\hline \multirow{2}{*}{ Model } & \multicolumn{2}{c}{ Unstandardized } & \multicolumn{2}{c}{$\begin{array}{c}\text { Standardizec } \\
\text { Coefficients }\end{array}$} & \multicolumn{2}{c}{ Coefficients } & \multirow{2}{*}{ T } & \multirow{2}{*}{ Sig. } \\
\cline { 2 - 5 } & $\mathrm{B}$ & Std. Err & Beta & & \\
\hline (Constant) & $74.88 `$ & 12.922 & & 5.795 & .000 \\
\hline keterlibatan kerja & .533 & .246 & .339 & 2.164 & .037 \\
\hline
\end{tabular}

a. Dependent Variable: produktivit;

$\mathrm{Y}=\mathrm{a}+\mathrm{bX}$

$\mathrm{Y}=74,882+0,246 \mathrm{X}$

Nilai konstanta sebesar 74,882 menunjukkan bahwa adanya pengaruh keterlibatan kerja terhadap produktivitas karyawan di Favehotel Olo Padang. Koefisien regresi sebesar 0,246 pada sig. $0,037 \leq 0,05$. Artinya setiap peningkatan sebesar 1 satuan keterlibatan kerja karyawan akan meningkatkan 0,246 satuan produktivitas karyawan.

\section{Pembahasan}

\section{Keterlibatan Kerja $(X)$}

Menurut Rivai dan Mulyadi (2012: 246) keterlibatan kerja adalah derajat sejauh mana seseorang memihak secara psikologis terhadap pekerjaanya dan menganggap tingkat kinerjanya penting untuk harga diri. Keterlibatan kerja merupakan suatu faktor yang penting dalam banyak kehidupan.

Berdasarkan hasil penelitian, dapat dijelaskan bahwa dari 38 orang sampel untuk variabel Keterlibatan Kerja dapat dikelompokkan sebagai berikut sebanyak 8 responden $(21,05 \%)$ menunjukkan kategori sangat baiK, 12 responden $(31,57 \%)$ menunjukkan kategori baik, 15 responden $(39,48 \%)$ menunjukkan kategori kurang baik, 3 responden $(7,90 \%)$ menunjukkan kategori tidak baik dan 0 responden $(0 \%)$ menunjukkan kategori sangat tidak baik. Berdasarkan hasil pengkategorian di atas, persentase tertinggi berada pada kategori kurang baik, dengan persentase 39,48\%. Keterlibatan Kerja di Favehotel Olo Padang dilihat dari tiga indikato yaitu: partisipasi kerja adalah dengan kategori baik serta memiliki persentase sebesar $34,21 \%$, keikutsertaan dengan kategori kurang baik serta memiliki persentase $42,12 \%$ dan kerja sama dengan kategori kurang baik dan memiliki persentase $44,73 \%$. Sehingga dapat 
disimpulkan bahwa Keterlibatan Kerja di Favehotel Olo Padang adalah dengan kategori kurang baik.

\section{Produktivitas $(Y)$}

Menurut Sunyoto (2015: 203), "Produktivitas kerja adalah ukuran yang menunjukkan pertimbangan antara input dan output yang dikeluarkan perusahaan serta peran tenaga kerja yang dimiliki persatuan waktu". Menurut Sutrisno (2011: 104) Produktivitas adalah hal yang sangat penting bagi para karyawan yang ada di perusahaan.

Berdasarkan hasil penelitian, dapat dijelaskan bahwa dari 38 orang sampel untuk variable Produktivitas Karyawan dapat dikelompokkan sebagai berikut: sebanyak 6 responden $(15,78 \%)$ menunjukkan kategori sangat baik, 16 responden $(42,10 \%)$ menunjukkan kategori baik, 15 responden $(39,48 \%)$ menunjukkan kategori kurang baik, 1 responden $(2,64 \%)$ menunjukkan hasil tidak baik dan 0 responden $(0 \%)$ menunjukkan hasil sangat tidak baik. Berdasarkan hasil pengkategorian di atas, persentase tertinggi berada pada kategori baik dengan persentase 42,10\%. Produktivitas karyawan di Favehotel Olo Padang dilihat dari enam indikator yaitu: Kemampuan dengan kategori baik dan memiliki persentase sebesar 39,47\%, meningkatkan hasil yang dicapai dengan kategori baik dan memiliki persentase sebesar $39,47 \%$, semangat kerja dengan kategori kurang baik dan memiliki persentase 47,37\%, pengembangan diri dengan kategori kurang baik dan memiliki persentase 47,38\%, mutu dengan kategori kurang baik dan memiliki persentase 39,47\% dan efisiensi dengan kategori kurang baik dan memiliki persentase $36,84 \%$. Sehingga dapat disimpulkan bahwa produktivitas karyawan di Favehotel Olo Padang adalah dengan kategori kurang baik.

Hasil penelitian uji hipotesis yang digunakan untuk mengetahui derajat pengaruh $\left(\mathrm{r}_{\mathrm{xy}}\right)$ antara Keterlibatan Kerja Terhadap Produktivitas Karyawan di Favehotel Olo Padang dengan menggunakan analisis SPSS 16.00 diperoleh nilai uji regresi linier sederhana antara keterlibatan kerja dengan produktivitas karyawan yang memiliki nilai konstanta sebesar 74,882 dan nilai koefisien regresi sebesar 0,246 dengan nilai signifikansi sebesar 0,037, artinya setiap peningkatan sebesar satu satuan Keterlibatan Kerja akan meningkatkan 0,246 satuan produktivitas, sedangkan hasil uji koefisien determinasi atau uji yang dilakukan untuk menyatakan besar atau kecilnya pengaruh variabel $\mathrm{X}$ terhadap $\mathrm{Y}$ yang ditentukan oleh nilai $R$ Square yaitu sebesar 0,115 artinya pengaruh variabel keterlibatan kerja terhadap produktivitas karyawan di Favehotel Olo Padang sebesar 11,5\% dan 88,5\% di pengaruhi oleh faktor lain, dengan interpretasi bahwa kedua variabel berpengaruh secara positif dan nilai signifikansi $<0,05$ yaitu sebesar 0,037 , sehingga $\mathrm{H}_{\mathrm{a}}$ diterima, artinya "terdapat pengaruh yang positif dan signifikan antara variabel keterlibatan kerja (X) terhadap produktivitas karyawan (Y) di Favehotel Olo Padang".

Berdasarkan uraian di atas dapat disimpulkan, bahwa terdapat pengaruh antara keterlibatan kerja di Favehotel Olo Padang dan produktivitas karyawan di kategorikan kurang baik

\section{Simpulan}

Secara keseluruhan keterlibatan kerja di Favehotel Olo padang tergolong kategori kurang baik yang berada pada skor $>40$ - $<50$ dengan persentase sebanyak $39,48 \%$ dan produktivitas karyawan di Favehotel Olo Padang tergolong kategori kurang baik yang berada pada skor $\geq 80-<100$ dengan persentase sebanyak $42,10 \%$. Hasil penelitian menunjukkan nilai koefisiensi regresi 0,246 signifikansi 0,037 dan koefisiensi determinasi yang di tunjukkan sebesar 11.5\% produktivitas di pengaruhi keterlibatan kerja dan sisanya sebesar $88,5 \%$ di pengaruhi oleh faktor lain yang tidak di teliti dalam penelitian ini. 


\section{Saran}

Berdasarkan pembahasan kesimpulan yang diperoleh, maka dapat diberi saran sebagai berikut:

\section{Manajemen Favehotel Olo Padang}

Disarankan agar pihak manajemen hotel diharapkan mempertahankan dan meningkatkan produktivitas karyawan terutama dalam keterlibatan kerja antara sesama karyawan dalam satu perusahaan untuk mendukung kelancaran operasional kerja. Manajemen hotel lebih memperhatikan lagi karyawan dengan tingkat keterlibatan kerja yang masih tergolong cukup pada indikator keikutsertaan dan kerja sama, dalam hal ini diharapkan mampu lebih mengayomi bawahannya agar merasa lebih diperhatikan maupun merasa lebih terbantu dan agar keterlibatan kerja mencapai kategori baik.

\section{Jurusan Pariwisata dan Perhotelan}

Kepada Jurusan Pariwisata dan Perhotelan agar dapat memberikan materi dan menyediakan bahan acuan mengenai produktivitas. Hal ini dikarenakan terbatasnya materi mengenai produktivitas tersebut. produktivitas merupakan salah satu ilmu yang penting untuk diketahui. Materi ini nantinya akan sangat berguna di dunia kerja, khusunya di bidang manajeman sumber daya manusia.

\section{Peneliti Berikutnya}

Bagi peneliti berikutnya disarankan agara dapat meneliti tentang faktor lain yang mempengaruhi produktivitas. Hal ini dikarenakan terdapat banyak faktor-faktor lain yang mempengaruhi produktivitas seperti pekerjaan yang menarik, upah yang baik, keamanan dan perlindungan dalam bekerja, disiplin kerja yang keras dan sebagainya.

\section{Bagi Penulis}

Bagi mahasiswa khususnya jurusan pariwisata dan perhotelan agar dapat meningkatkan wawasan tentang faktor- faktor lain yang dapat mempengaruhi produktivitas karyawan di perusahaan

\section{Daftar Pustaka}

Anoraga, P. 2009. Psikologi Kerja. Jakarta:Rineka Cipta.

Rivai dan Mulyadi. 2012. Kepemimpinan dan Prilaku Organisasi Edisi Ketiga. Jakarta: PT. Rajagrafindo Persada.

Sedarmayanti. 2009. Sumber Daya Manusia dan Produktivitas Kerja. Bandung: Cv. Mandar Maju.

Sugiyono. 2013. Metode Penelitian Kuantitatif Kualitatif dan R\&D. Bandung: Alfabeta.

Sulastiyono. 2011. Manajemen Penyelenggaraan Hotel: Manajemen Hotel, bandung: Alfabeta

Sunyoto. 2015. Manajemen dan Pengembangan Sumber Daya Manusia. Jakarta: PT. Buku Seru.

Sutrisno. 2011. Manajemen Sumber Daya Manusia Edisi Pertama. Jakarta: Kencana Prenada Media Grup.

Via Gusti, Yuliana dan Hijriyantomi Suyuthie. 2015. Pengaruh komunikasi interpersonal terhadap produktivitas kerja karyawan di grand rocky hotel bukittingi: http://ejournal.unp.ac.id/index.php//hht/article/view/4507 di akses tanggal 17 Juli 2019 